\title{
IMPLEMENTASI PEMBELAJARAN PENDIDIKAN AGAMA ISLAM BERWAWASAN REKONTRUKSI SOSIAL
}

\author{
Ririn Suneti \\ Mahasiswa Program Studi Manajemen Pendidikan Islam \\ PPs UIN Maliki Malang
}

\begin{abstract}
Social reconstruction, assuming that humans are social beings who always live together, interact, collaborate, and other human needs. Therefore, social recpntrcution contradictories from the problems faced the community, to further the role of science and technology, and also working cooperatively, collaboratively, and looked for a solution to establish a better society. In these circumstances, it is necessary to have "social reconstruction curriculum" which is able to prepare students in developing their basic potential as individuals and social beings and and also ready to accept all the changes through learning PAI forward. The process of strategic vision implementation of Islamic learning social reconstruction can provide learning which leads to life problems faced by the students and the community. Therefore, the practical education of students depends on their interests and needs of people through Islamic education learning by using social reconstruction curriculum.
\end{abstract}

Keywords: Curriculum, social reconstruction, PAI learning (Islamic education learning)

\section{A. Pendahuluan}

Dalam undang-undang No. 2/1989 tentang sistem pendidikan nasional, dinyatakan bahwa pendidikan Agama wajib diberikan pada setiap jalur, jenis, dan jenjang pendidikan. Sayangnya, kualitas pembelajaran pendidikan kita menurut berbagai indikator belum sesuai dengan yang diharapkan, khususnya pendidikan dasar dan menengah (Direktorat SLTP, 2002). Pembelajaran PAI sering berorientasi pada penguasaan materi yang tersimpan dalam otak siswa dan bersifat normative (Mulkan, et. al Abdullah, Amir1998:49-65). Akibatnya siswa dan pendidik merasa terbebani untuk menyelesaikan materi tanpa 


\section{Ririn Suneti - Implementasi Pembelajaran Pendidikan ...}

berfikir ke depan atas pengaruh dari pembelajaran akhlaqul karimah tersebut, dan hasilnya pun tidak optimal.

Kekecewaan pembelajaran PAI, merupakan tanda-tanda adanya ketidakpuasan dalam pelayanan pendidikan atau kualitasnya rendah. Diantara kritikyang patutkita cermatiadalah berikutini:(1)Pendidikan agama Islam (PAI) lebih terkonsentrasi pada persoalan-persoalan teoritis keagaman yang bersifat kognitif semata serta amalan-amalan iabadah praktis, dan lebih berorientasi pada belajar tentang, kurang konsern terhadap persoalan bagaimana mengubah pengetahuan agama yang koqnitif menjadi menjadi "makna" dan "nilai" yang perlu diinternalisasikan dalam diri siswa. (2) Metodologi PAI tidak kunjung berubah, ia berjalan secara konvensional-tradisional, dan monoton. (3) Kegiatan PAI kebanyakan menyendiri, kurang berinteraksi dengan yang lain, bersifat marjinal dan periferal.(4) Pendekatan PAI cenderung normatif, tanpa ilustrasi konteks sosial budaya. (5) Guru PAI sering terpaku pada GPAI mata pelajaran PAI. (6) Guru PAI lebih bernuansa guru spiritual/moral dan kurang diimbangi dengan nuansa intelektual dan profesional, dan suasana guru dengan siswa lebih berspektif doktriner, kurang tercipta suasana kritis-dinamis yang dapat berimplikasi dan berkonsekuensi pada peningkatan daya kreativitas, etos ilmu dan etos kerja/amal (Muhaimin 2002:111). Beberapa kritik atas kondisi PAI yang berkembang sampai saat ini senantiasa lebih bersifat ajakan untuk melakukan perubahan, karena bagaimanapun keberadaan PAI dirasakan sangat urgen dan mampu memberi kontribusi terhadap peningkatan keimanan dan ketaqwaan para siswa.

Keberadaan PAI dirasakan memberi kontribusi terhadap mutu para siswa, karena pendidikan merupakan bimbingan secara sadar oleh sipendidik terhadap perkembangan jasmani dan rohani siterdidik menuju kepribadian yang utama (Ahmad D. Marimba, 1980:19). Fungsi pendidikan Islam adalah sebagai (1) upaya menumbuhkan kreativitas peserta didik secara berkelanjutan (2) upaya memperkaya khazanah budaya manusia, memperkaya isi nilai-nilai insani dan ilahi dan (3) upaya menyiapkan tenaga kerja yang produktif yang mampu mengantisipasi masa depan dan/atau mampu memberi corak struktur kerja masa depan yang dijiwai oleh spirit Islam (Muhaimin, 2003:44). Pendidikan Islam lebih banyak ditujukan kepada perbaikan sikap mental yang akan terwujud dalam amal perbuatan untuk diri dan 
lingkungannya, karena itu keberadaan PAI di sekolah merupakan pendidikan iman dan sekaligus pendidikan amal (Zakiah Daradjat, 1991:28). Dengan kata lain pendidikan itu "menentukan" model manusia yang akan dihasilkannya (Nana Syaodih Sukmadinata, 1999:38).

Sebagai upaya "menentukan" model manusia yang akan dihasilkan, maka praksis pendidikannya harus sesuai dengan minat siswa dan kebutuhan masyarakat. Untuk memenuhi kebutuhan tersebut, setidaknya perlu dikembangkan kurikulum yang cepat merespon tuntutan-tuntutan yang ada pada masa sekarang dan yang akan terjadi di masa mendatang, serta komitmen terhadap pengembangan kreativitas yang berkelanjutan. Dengan demikian, permasalahan yang perlu dijawab adalah bagaimana "kurikulum" itu dibuat agar bisa menjadi (1) penunjuk arah, (2) bentuk manusia, dan (3) konteks social yang diinginkan. Karena menyiapkan kurikulum yang sesuai dengan kebutuhan, berari ikut menentukan "proses pelaksaan" dan "hasil" pendidikan, atau bisa jadi jika kurikulumnya lemah maka sama halnya menyiapkan gagalnya pendidikan.

Dalam kondisi demikian, pengembangan kurikulum yang cepat merespon tuntutan di masa sekarang dan yang akan terjadi di masa mendatang serta tetap memiliki kualitas keimanan dalam diri siswa, merupakan kebutuhan mutlak para siswa. Karena itulah dalam tulisan ini dipilih "kurikulum rekontruksi sosial" sebagai implementasi pembelajaran PAI ke depan guna menyiapan peserta didik dalam mengembangkan potensi dasarnya sebagai makhluk individu dan sosial serta siap menerima segala perubahan.

\section{B. Hakikat Pembelajaran Rekonstruksi Social}

Pada hakikatnya rekontruksi sosial, berasumsi bahwa manusia adalah sebagai makhluk sosial yang dalam kehidupannya selalu membutuhkan manusia lain, selalu hidup bersama, berinteraksi dan bekerja sama (Muhaimin, 2005:173). Ia hanya dapat berkembang dan menjadi sempurna karena hidup bersama orang lain (Suparno, Paul. Dkk, 2002:12).

Kemampuan siswa akan terbukti sedemikian rupa, karena ia mempunyai potensi tumbuh dan berkembang sesuai dengan karakteristiknya untuk bereaksi dalam konteks sosial. Aksi manusia itu, 


\section{Ririn Suneti - Implementasi Pembelajaran Pendidikan ...}

perlu ditumbuhkan menjadi kreatif, situasi dan lingkunganpun tidak dibiarkan sebagai mana adanya. Dan manusia tidak membiarkan dirinya hanyut pada perubahan yang terjadi, karena manusia mempuanyai idealisme dan cita rasa bagi masyarakat masa depan (Noeng Muhadjir, 2000:94). Inilah proses utama pendidikan yakni berusaha menumbuhkan kesadaran masing-masing diri siswa untuk lebih aktif bersentuan dengan realitas kehidupan yang sesungghnya. Harkat dan martabat siswa yang ditumbuhkan dalam pendidikan, sesungguhnnya berguna juga untuk memotivasi perubahan masyarakat sosial dimana ia hidup dan berkembang.

Potensi siswa dalam rekontruksi sosial ini setidaknya dibantu, dan benar-benar diarahkan agar siswa menjadi cakap, terampil serta selanjutnya ikut bertanggung jawab terhadap pengembangan masyarakatnya. Hal itu sesuai dengan watak dan proses pendidikan yang dibutuhkan saat ini. Menurut Noeng Muhadjir rekontruksi sosial bukan dirancang secara top down, melainkan tumbuh dan berkembangnya secara bottom-up (Noeng Muhadjir, 2000:95). Sedangkan isi pendidikannya terdiri atas problem aktual yang dihadapi oleh kehidupan nyata berbentuk kelompok, mengutamakan kerja sama, baik antar peserta didik dengan guru/dosen dengan sumber-sumber belajar yang lain (Muhaimin, 2005:173). Untuk itulah rekontruksi sosial bertolak dari problem yang dihadapi dalam masyarakat, untuk selanjutnya dengan memerankan ilmu-ilmu dan teknologi, serta bekerja secara kooperatif, kolaboratif, dan dicarikan pemecahannya menuju pembentukan masyarakat yang lebih baik. Dalam rekontruksi sosial ini, selain isi pembelajaran, juga sekaligus menekankan proses pendidikan dan pengalaman belajar (Muhaimin, 2005:174).

Mengingat rekontruksi sosial lebih mengutamakan isi, proses dan pengalaman, maka dapat dikatakan hakikat dari pembelajaran rekontruksi sosial sendiri tidak lain adalah memberikan kebebasan siswa agar tidak terjadi kemandulan dalam berpikir. Hal ini dikarenakan keberadaan siswa adalah sebagai makhluk hidup yang berakal, mempunyai nurani dan selalu berhadapan dengan masyarakar. Dari sini, sangat relevan bila rekontruksi sosial dikatakan memgutamakan "pembebasan" siswa untuk lebih giat mempelajari problem-problem sosial yang sedang dihadapai masyarakat. Problem ini sebagai isinya, sedangkan prosesnya dapat dilakukan dengan dialog dan pemecahan masalah. 
Dengan demikian hakikat pembelajaran rekontruksi sosial adalah memberikan pelayanan dalam prose belajar secara aktif, karena siswa menjadi aktif dan partisipatif. Siswa memiliki kesadaran akan problem sosial, politik ekonomi umat manusia, siswa memiliki ketrampilan untuk memecahkan problem tersebut dan akhirnya membangun tatanan baru. Keberdaan rekontruksi sosial dalam arti fungsi pendidikan ini dimaksudkan agar anak didik menajdi cakap dan kreatif, sekaligus mampu memanfatkan potensi yang sudah di asah melalui pengalaman. Sehingga dalam rekontruksi sosial ini, sungguh dengan kecakapan dan kreatifitasnya ini, siswa tidak lagi sebagai anak yang minder, tidak bebas menggunakan pikirannya untuk belajar, akan tetapi - menurut bahasa P. Muhaimin - ia sekaligus mampu bertanggung jawab untuk turut serta dalam mengembangkan masyarakatnya (Muhaimin, 2003:27).

Pembelajaran yang mengarahkan pada kecakapan dan kreatifitas, keberadaan "siswa" ini bagi Noeng Muhadjir digolongkan sebagai pelaku sosial yang kritis-kreatif, karena ia mampu menyadari konsekwensi bila pengetahuan, ketrampilan, keahlian, dan wawasannya menjadi tertinggal, akan membuat dia terpuruk. Sebagai pelaku sosial yang kritis-kreatif, siswa akan berupaya untuk mencari peluang agar ia dapat sukses berkelanjutan dalam percepatan perubahan sosial (Noeng Muhadjir, 2000:95).

Ciri siswa sebagai pelaku sosial yang kritis-kreatif ini tidak jauh dari gagasan Paulo Freire, karena ia memberikan alternatif atas pembelajaran yang benar-benar membuat suasana hidup dan membangkitnkan potensi siswa. Hal ini dapat dilihat dari "cara" memperlakukan siswa dalam "belajar". Ia menginginkan, agar tiap individu turut aktif mengadakan perubahan yang diinginkan.

Siswa yang kritis-kreatif ini, sungguh dampak dari pembelajaran rekontruksi sosial. Mengingat siswa dalam pendidikan adalah pelaku pendidikan, bukanlah objek. Karena itu, potensi siswa ini dalam wacana rekontruksi sosial benar-beanar dibantu dan diarahkan, agar kecakapan, ketrampilansiswa menyatu dalamkehidupannya, akhirnya ia bertanggung jawab terhadap pengembangan masyarakatnya.

\section{Kurikulum Rekontruksi Sosial: Implementasi Pembelajaran PAI ke Depan}




\section{Ririn Suneti - Implementasi Pembelajaran Pendidikan ...}

Sejalan dengan keadaan masyarakat yang selalu berubah sesuai dengan tuntutan zaman, maka dalam pembelajaran PAI ke depan juga diusahakan dapat merespon segala problem dan fenomena yang dihadapi masyarakat. Problem yang sering kali muncul di tengahtengah kehidupan siswa tersebut merupakan alternatif peningkatan mutu siswa sebagai pelaku sosial yang kritis-kreatif. Mengapa hal ini perlu dilakukan?. Karena "sekolah" adalah agen perubahan masyarakat, oleh karena itu pendidikan harus disesuaikan dengan (1) minat siswa dan (2) kebutuhan masyarakat. Sedangkan "kurikulum" dibuat agar bisa menjadi (1) penunjuk arah, (2) bentuk manusia, dan (3) konteks sosial yang diinginkan.

Kurikulum rekontruksi sosial, itu lebih pada tugas pendidikan sebagai upaya pengembangan aspek individu dan sekaligus sebagai pengembangan aspek tanggung jawab kemasyarakatan, serta lebih bersikap proaktif dan anti-sipatif dalam menghadapai permasalahan bangsa Indonesia di masa depan (Muhaimin, 2004:14). Sebab secara ekplisit, ahli rekontruksi sosial lebih menghendaki keberadaan sekolah untuk menyiapkan siswa memiliki tanggung jawab pribadi dan sekaligus bertaggung jawab guna menghadapi perubahan masyarakat.

Sebagaimana yang dikemukakan oleh ahli rekontruksi sosial, bahwa adanya "perubahan" itu merupakan dampak dari aktivitas pendidikan yang sebelumnya telah direncanakan di sekolah atau lembaga pendidikan tinggi. Munculnya perubahan, tidak lain dari kreativitas manusia menghadapi berbagai isu atau dilema dimanapun mereka berada. Rekontruksi sosial memfokuskan kurikulum masalah-masalah penting yang dihadapi dalam mayarakat, misalkan kemiskinan, malapetaka terhadap kemajuan teknologi, hak asasi manusia, keadilan dan lain sebagainya (Nasution, 1986:47). Karena itu, "problem" yang sering kali muncul di tengah-tengayh kehidupan siswa tersebut merupakan alternatif untuk dijadikan reverensi pengembangan kurikulum. Mengapa hal ini perlu dilakukan?. Karena "sekolah" adalah agen perubahan masyarakat, oleh karena itu pendidikan harus disesuaikan dengan (1) minat siswa dan (2) kebutuhan masyarakat. Sedangkan "kurikulum" dibuat agar bisa menjadi (1) penunjuk arah, (2) bentuk manusia, dan (3) konteks sosial yang diinginkan.

Secara ekplisit dapat dikatakan bahwa ahli rekontruksi sosial le- 
bih menghendaki keberadaan sekolah untuk menyiapkan siswa memiliki tanggung jawab pribadi dan sekaligus bertaggung jawab guna menghadapi perubahan masyarakat. Hal ini sejalan dengan Muhaimin (2004:14) bahwa tipologi rekontruksi sosial lebih pada tugas pendidikan sebagai upaya pengembangan aspek individu dan sekaligus sebagai pengembangan aspek tanggung jawab kemasyarakatan, serta lebih bersikap proaktif dan anti-sipatif dalam menghadapai permasalahan bangasa Indonesia di masa depan.

Selama ini pendidikan hanya dianggap sebagai sebuah proses belajar mengajar saja, dengan tanpa terlalu mengindahkan nilainilai kemanusiaan (tidak manusiawi) serta nilai-nilai kebebasan. Kurikulum yang dijalankan pun terkesan hanya sebagai alat mikanis yang tak manusiawi juga. Mungkin hal tersebutlah yang menjadi pusat penyebab "pemberontakan" siswa atas kondisi yang sesungguhnya, tapi ia tak kuasa merealisasikannya. Dari pengalaman ini, setidaknya keberadaan "sekolah" yang dikatakan sebagai agen perubahan masyarakat, dapat diimplementasikan melalui kurikulum berwawasan rekontruksi sosial. Untuk menghadirkan suasana guna melakukan perubahan sosial, tugas pokok sekolah adalah memandirikan siswa, hal ini terkait dengan proses pendidikan (Paul Suparno, dkk, 2001:65).

Implementasi pembelajaran PAI berwawasan rekontruksi sosial ini memiliki makna bahwa dalam pembelajaran tersebut ada kegiatan memilih, menetapkan dan mengembangkan metode/strategi yang optimal untuk mencapai hasil yang diinginkan dalam kondisi tertentu (Muhaimin, dkk.1996:132). Secara sederhana, bahwa proses pembelajaran PAI tersebut telah berlangsung sesuai dengan rencana untuk menghasilkan "yang diinginkan dalam kondisi tertentu", sehingga menimbulkan suasana baru yakni "siswa benar-benar belajar". Bukankah pembelajaran juga merupakan upaya untuk membelajarkan peserta didik?. Karena itu dalam pembelajaran berwawasan rekontruksi sosial ini perlu kiranya diimplementasikan dalam PAI.

Salah satu proses strategis implementasi pembelajaran PAI. berwawasan rekontruksi sosial ini dapat memberikan pembelajaran yang mengarah pada problem hidup. Dari sini, siswa dilatih untuk mengemukakan berbagai macam ide dan menentukan pilihan-pilihan. Sehingga tampak bahwa guru tidak memposisikan siswa sebagai 


\section{Ririn Suneti - Implementasi Pembelajaran Pendidikan ...}

obyek yang tidak tahu apa-apa. Akan tetapi siswa benar-benar paham terhadap realitas kehidupan. Hal demikian ini, sebagaimana yang tertuang dalam gagasan-gagasan tentang hakikat pendidikan sebagaimana yang didasarkan pada pandangan Freire tentang manusia dan dunia. Karena itu pendidikan harus berorientasi pada pengenalan realitas diri manusia dan dirinya sendiri. Di sisi lain pakar rekontruksi sosial ini juga mengungkapkan bahwa proses pendidikan itu akan merangsang ke arah diambilnya tindakan yang kemudian direfleksikan kembali dan dari refleksi tersebut diambil tindakan baru yang lebih baik. Demikian seterusnya sehingga proses pendidikan merupakan satu daur bertindak dan berfikir secara terus menerus sepanjang hidup seseorang. Perhatikan gambar berikut:

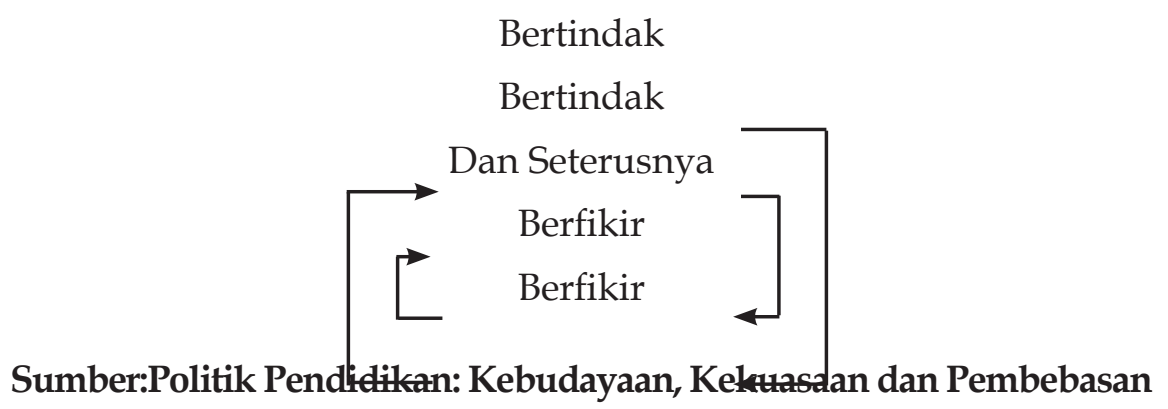

(Freire, 1999:xiv)

Skema "satu daur bertindak dan berfikir" tersebut di atas, merupakan acuan berpikir siswa dalam pembelajaran PAI berwawasan rekontruksi sosial. Karena dapat diimplementasikan sebagaimana yang dikembangkan ke arah yang bersifat teosentris atau berlandaskan tauhid dalam pembelajaran pendidikan agama Islam.

Dalam khazanh pemikiran Islam, setidaknya terdapat empat macam konsep tauhid, yaitu tauhid uluhiyah, tauhid rububiyah, tauhid mulkiyah dan konsep tauhid rahmaniyah. Untuk bisa menghasilakn suatu pribadi yang integral melalui proses pendidikan, maka keempat konsep tauhid tersebut perlu diintregasikan menjadi suatu konsep yang holistic (Daam Rahardjo, 1993:430-442). Di saat proses mengintregsikan inilah, peran satu daur bertindak dan berfikir secara terus menerus sepanjang hidup seseorang sangat berguna bagi siswa untuk menguatkan suatu pribadi yang integral. 
Implementasi rekontruksi sosial, yang berlandaskan tauhid sebenarnya senada dengan penanaman dasar pada siswa yang di_lakukan oleh pendidikan Islam. Sebab pendidikan agama Islam sebenarnya berupaya mengembangkan potensi siswa untuk maju. Teori rekontruksi sosialpun berpendapat, bahwa pendidikan agama Islam itu bertujuan untuk meningkatkan kepedulian dan kesadaran peserta didik akan masalah yang dihadapi oleh umat manusia, yang merupakan bagian dari kewajiban dan tanggung jawab pemeluk agama Islam untuk memecahkannya melalui da'wah bi al-hal. Baik yang terkait dengan masalah sosial, ekonomi, politik dan budaya atau yang lainnya dan mengajarkan ketrampilan-ketrampilan yang diperlukan untuk memecahkan semua problem tersebut agar dapat berpartisipasi dalam melakukan islah (perbikan) dan amar ma'ruf nahi munkar sehingga dapat terwujud suatu tatanan masyarakat baru yang lebih baik (Muhaimin, 2004:25). Hal ini membuktikan bahwa pendidikan Islam adalah pendidikan iman dan sekaligus pendidikan amal (Zakiyah Darajat, 1991:28).

Sebagaimana uraian terdahulu, bahwa kurikulum rekonstruksional disamping menekankan pada isi pembelajaran juga menekankan proses pendidikan dan pengalaman belajar (Muhaimin, 2005:173). Proses pendidikan dan pengalaman belajar siswa ini dalam pandangan pakar rekontruksi sosial disebut dengan pendidikan hadap masalah bukan pendidikan gaya bank. Karena itulah, pendekatan rekontruksi sosial berasumsi bahwa manusia adalah makhluk sosial yang dalam kehidupannya selalu membutuhkan manusia lain, selalu hidup bersama, berinteraksi dan bekerja sama. Sehingga tugas pendidikan adalah membantu agar peserta didik menjadi cakap dan selanjutnya mampu ikut bertanggung jawab terhadap masyarakatnya (Muhaimin, 2005:173). Berikut ini model Pembelajaran PAI Berwawasan Rekontruksi Sosial. 
Ririn Suneti - Implementasi Pembelajaran Pendidikan ...

Model Pembelajaran PAI Berwawasan

Rekontruksi Sosial Masyarakat (Society)

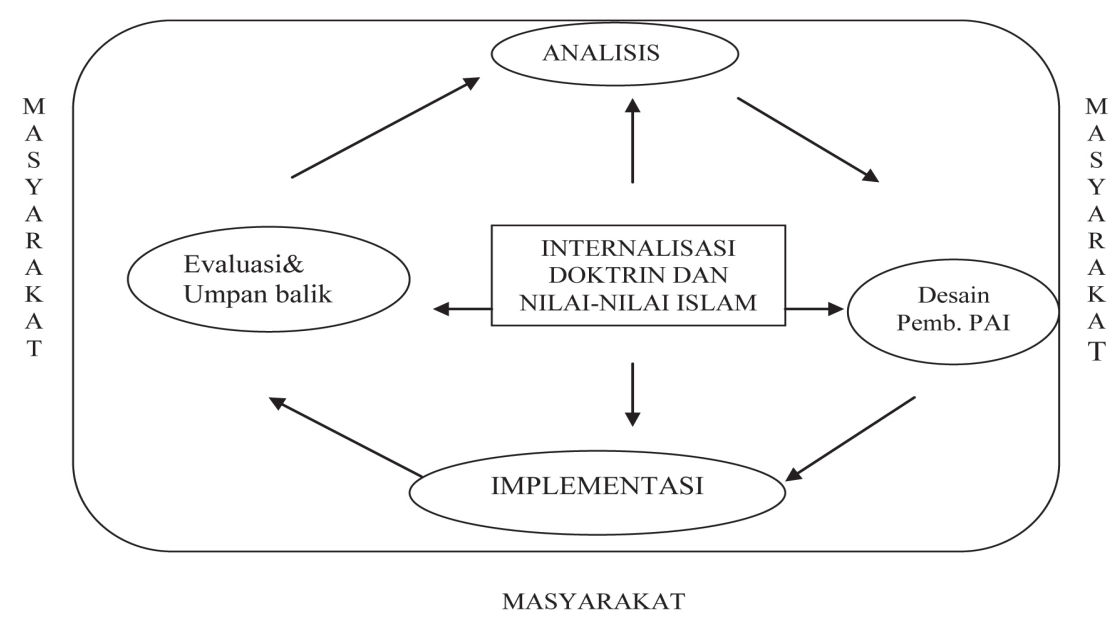

Sejalan dengan gambar di atas, peserta didik terjun ke masyarakat dan dilandasi oleh internalisasi nilai dan ajaran-ajaran Islam. Artinya setiap gerak dan langkah dalam beraktivitas dilandasi oleh niat yang suci sebagaimana yang terkandung dalam Al-Qur'an dan Hadist Rasulullah SAW. Serta berusaha membangun (kembali) masyarakat atas dasar komitmen, dedikasi sebagai pelaku terhadap ajaran dan nilai-nilai Islam.

Mekipun demikian, tapi diperlukan kerjasama dengan orang tua dan masyarakat yang menjadi pilot proyek. Prosedur kerjanya dapat dilakukan melalui tahapan-tahapan sebagai berikut.

1. GPAI bekerja sama dengan peserta didik melakukan studi kelayakan untuk penentuan program proyek dilokasi. Misalnya dengan kegiatan sebagai berikut:

(1) Pengurusan prosedur administratif untuk measuki desa lokasi.

(2) Orientasi wilayah untuk mengidentifikasi masalah-masalah yang terkait dengan tema pembelajaran.

(3) Penentuan tema pokok untuk pembelajaran PAI sesuai dengan skala prioritas di wilayah tersebut.

2. Pembentukan Tim Kerja 
Terdiri atas, tim ahli (guru GPAI) dan tim pelaksana kerja proyek (peserta didik).

3. Tugas-tugas Tim Kerja

a) Tim ahli bertugas (a) untuk mengelola administrasi kerja proyek di lapangan. (b) memberikan pendidikan dan pelatian kepada peserta didik sebagai tim Pelaksana Kerja Proyek. (c) mempekenalkan ide pengembangan dakwah kepada tokoh masyarakat dan pejabat setempat. (d) bersama-sama dengan Tim Pelaksana Kerja Proyek menyusun program kerja sesuai dengan tema program pembelajaran PAI. (e) memonitor atau mengevaluasi proses dan hasil pelaksanaan program kerja proyek. (f) mempertanggungjawabkan hasil kerja proyek (dalam bentuk laporan tertulis) kepada kepala sekolah / madrasah, tokoh masyarakat/pejabat setempat.

b) Tim Pelaksana Kerja Proyek bertugas (a) memperkenalkan ide pengembangan dakwah kepada masyarakat sesuai dengan tema pembelajaran PAI yang ditetapkan hingga mereka setuju dengan ide tersebut. (b) bersama-sama dengan Tim Ahli dan masyarakat berusaha menggali masalah-masalah yang terkait dengan tema pembelajaran Pai yang ditetapkan. (c) memprioritaskan bidangbidang program. (d) menyusun program bekerja sama dengan Tim Ahli dan tokoh masyarakat setempat. (e) melaksanakan program yang ditetapkan. (f) memonitor dan/mengevaluasi proses dan hasil pelaksanaan perogram serta mempertanggungjawabkannya kepada Tim Ahli

c) Pendidikan dan Pelatian Tim Pelaksana Kerja

d) Sebelum Tim Pelaksana Kerja di Terjunkan ke lapangan, maka perlu diadakan pendidikan dan pelatian.

e) Pendekatan/Meode pendidikan dan pelatian dapat berbentuk (1) ceramah dan tanya jawab.(2) diskusi. (3) problrm solving. (4) pemberian tugas.

f) Waktu pelaksanaannya di luar jam belajar di sekolah/madrasah, sedangkan tempatnya dapat di kelas atau luar kelas, sesuai dengan karakteristik materinya.

4. Langkah-langkah Pelaksana Program Kerja adalah sebagai berikut. 


\section{Ririn Suneti - Implementasi Pembelajaran Pendidikan ...}

a) Tim pelaksana kerja memperkenalkan tema pembelajaran PAI kepada masyarakat.

b) Tim pelaksana kerja bersama-sama dengan tokoh masyarakat/ pejabat setempat berusaha menggali masalah-masalah yang terkait dengan tema pembelajaran PAI yang ditetapkan dengan cara musyawarah.

c) Tim Pelaksana Kerja Proyek bekerja sama dengan Tim Ahli dan tokoh masyarakat setempat menyusun program bekerja dan menetapkan prioritas bidang-bidang program,

d) Tim Pelaksana Kerja Proyek melaksanakan program kerja bersama tokoh masyarakat.

e) Tahap demi tahap pelaksana proyek menyerahkan pelaksanaan kerja kepada tokoh dan kader masyarakat setempat.

f) Tim pelaksana kerja memonitor dan/mengevaluasi proses dan hasil program kerja (dalam bentuk tulisan kepada Tim Ahli)

g) Tim Ahli (GPAI) memonitor, mengevaluasi dan melaporkan proses dan hasil program kerja kepala sekolah/madrasah, tokoh masyarakat atau pejabat setemmpat (Muhaimin, 2005:179-181).

Lagkah-langkah tersebut merupakan tawaran atas berbagai kritik pembelajaran PAI selama ini di sekolah. Adapun berbagai kritik tersebut menyoroti seputar "pembelajaran" PAI yang terkesan hanya berkonsentrasi pada persoalan-persoalan teoritis keagaman yang bersifat kognitif semata serta amalan-amalan iabadah praktis, dan lebih berorientasi pada belajar tentang, kurang konsern terhadap persoalan bagaimana mengubah pengetahuan agama yang koqnitif menjadi menjadi "makna" dan "nilai" yang perlu diinternalisasikan dalam diri siswa.

Bertolak dari gagasan rekontruksi sosial, dapat dipastikan kesan "sekolah belum menjadi sarana pendidikan yang menyenangkan" dan "memberikan pengetahuan yang bermakna bagi peserta didik". sebagai dampaknya saat ini adalah, (1) sekolah terlalu banyak membebani siswa dengan pengetahuan yang banyak, namun tidak bermakna.(2) Tidak heran kalau pengetahuan yang diberikan itu tidak bisa dijadikan topangan keterampilan yang berkembang secara dinamis. Akibatnya, peserta didik kita sulit bersaing dengan tenaga kerja asing, dan peserta didik kita tidak mampu akan lemah mewujudkan sikap 
yang mandiri.

Dengan kritikan tersebut, menurut Malik Fadjar, setidaknya dunia pendidikan membutuhkan perubahan pola pikir, yakni dari sekadar mengikuti petunjuk mejadi lebih mandiri dan bisa berpikir secara kreatif. Dalam desain manajemen pendidikan berbasis sekolah, sebenarnya sudah memberikan peluang pada pengelola sekolah untuk memberikan apa yang dibutuhkan siswa secara cepat (..... Kompas, Jum'at, 28 Februari 2003). Dari sinilah semakin terasa bahwa "perubahan pola pikir" dan "bisa berpikir secara kreatif" yang berjiwa tauhid benar-benar merupakan kebutuhan mutlak bagi siswa masam kini dan mendatang.

Sebagaimana yang dikemukakan oleh ahli rekontruksi sosial, bahwa adanya "perubahan" itu merupakan dampak dari aktivitas pendidikan yang sebelumnya telah direncanakan di sekolah atau lembaga pendidikan tinggi. Munculnya perubahan, tidak lain dari kreativitas manusia menghadapi berbagai isu atau dilema dimanapun mereka berada. Rekontruksi sosial memfokuskan kurikulum masalah-masalah penting yang dihadapi dalam mayarakat, misalkan kemiskinan, malapetaka terhadap kemajuan teknologi, hak asasi manusia, keadilan dan lain sebagainya (Nasution, 1986:47). Karena itu, "problem" yang sering kali muncul di tengah-tengan kehidupan siswa tersebut merupakan alternatif untuk dijadikan reverensi pengembangan kurikulum. Mengapa hal ini perlu dilakukan?. "Sekolah" adalah agen perubahan masyarakat, oleh karena itu pendidikan harus disesuaikan dengan (1) minat siswa dan (2) kebutuhan masyarakat. Sedangkan "kurikulum" dibuat agar bisa menjadi (1) penunjuk arah, (2) bentuk manusia, dan (3) konteks sosial yang diinginkan.

Secara ekplisit Muhaimin (2004:14) menjelaskan kembali bahwa rekontruksi sosial ini lebih mengarah pada tugas pendidikan sebagai upaya pengembangan aspek individu dan sekaligus sebagai pengembangan aspek tanggung jawab kemasyarakatan, serta lebih bersikap proaktif dan anti-sipatif dalam menghadapi permasalahan bangasa Indonesia di masa depan (Muhaimin, 2004:14). Karena itu, rekontruksi sosial dalam menyusun kurikulum ini betolak dari problem yang dihadapi dalam masyarakat, selanjutnya dengan memerankan ilmu-ilmu dan teknologi, serta bekerja secara kooperatif, kolaboratif, dan dicarikan pemecahannya menuju pembentukan masyarakat yang 


\section{Ririn Suneti - Implementasi Pembelajaran Pendidikan ...}

lebih baik. Pada akhirnya rekontruksi sosial ini, menekankan pada komponen isi pembelajaran dan sekaligus proses pendidikan serta pengalaman belajar. Di samping itu, tidak bisa lepas dari pemikiran tentang eksistensi "manusia" sebagai makhluk sosial karena selalu membutuhkan manusia lain, hidup bersama, berinteraksi dan bekerja sama (Muhaimin, 2003:150).

Dengan demikian, kurikulum rekontruksi sosial merupakan suatu program yang di desain, direncanakan, dikembangkan, dan dilaksanakan dalam situasi belajar mengajar yang sengaja diciptakan di sekolah. Berdasarkan pemikiran tersebut tersebut, kurikulum rekontruksi sosial itu merupakan "alat" untuk menghasilkan pembelajaran PAI yang sesuai dengan kebutuhan siswa dan masyarakat, sehingga akhirnya memperoleh lulusan yang berkualitas secara individu dan sekaligus bertanggung jawab di ligkungan kemasyarakatan, serta lebih bersikap proaktif dan anti-sipatif dalam menghadapai permasalahan di masa depan.

Sejalan dengan karakteristik "kurikulum" yang tidak statis, maka keberadaan rekontruksi sosial pun akan menjadi bahan pilihan masyarakat yang dinamis. Penyesuaian kurikulum dengan kebutuhan masyarakat yang akan disampaikan pada siswa, berarti memberi peluang pada siswa guna merubah pengetahuan dari pembelajaran yang bersifat pengetahuan mengarah pada praksis di realitas kehidupan bersama.

Peluang atau kesempatan mengembangkan kurikulum rekontruksi sosial sebenarnya langkah praktis dan strategis, karena melayani dan menyiapkan kegiatan pembelajaran siswa dengan berbagai materi dan pengalaman yang disesuaikan dengan kebutuhan siswa, termasuk isu-isu yang berkembang di mayarakat terutama berbagai macam dilema yang dirasakan langsung oleh siswa juga menjadi bagian dari kebutuhan pengembangan kurikulum rekontrusi sosial. Di sinilah peran pendidikan Islam, yakni berupaya menumbuhkan kreativitas peserta didik, memperkaya khazanah budaya manusia, memperkaya isi materi dengan nilai-nilai insani, ilahi serta menyiapkan tenaga kerja produktif yang mampu mengantisipasi masa depan.

\section{Penutup}

Kualitas pembelajaran pendidikan agama Islam, belum sesuai 
dengan harapan. Pembelajaran PAI ini sering berorientasi pada penguasaan materi dan bersifat normatif. Akibatnya siswa dan pendidik terbebani untuk menyelesaikan materi tanpa berfikir ke depan. Peran PAI harus mampu memberi kontribusi terhadap peningkatan keimanan dan ketaqwaan para siswa, akhirnya "menentukan" model manusia yang akan dihasilkannya.

Guna menjawab peluang sesaui tuntutan dan perubahan, tampaknya implementasi kurikulum rekontruksi sosial memiliki peran yang strategis. Hal ini dikarenakan melayani dan menyiapkan kegiatan pembelajaran siswa dengan berbagai materi dan pengalaman yang disesuaikan dengan kebutuhan siswa, termasuk isu-isu yang berkembang di mayarakat,. Dengan demikian "pendidikan Islam" benar-benar berupaya menumbuhkan kreativitas peserta didik, menjadi trampil guna mengantisipasi masa depan yang dijiwai spirit Islam.

Oleh karena itu, pembelajaran berwawasn rekontruksi sosial merupakan alternatif "kurikulum" yang dapat diimplementasikan dalam pandidikan agama Islam, karena dikembangkan dengan mempertimbangkan kebutuhan masyarakat. Cara ini akin mudah diterima oleh mayarakat atau siswa-siswi, karena rekontruksi sosial tidak mementikan salah satu keberhasilan dalam pengembangan kurikulum. Akin tetapi yang ditekankan ada isi kurikulum dan sekaligus proses yang harus dialami pendidik juga menjadi perhatian rekontruksi sosial. Dasar rekontruksi sosial inilah yang membedakan dengan lainnya.

\section{E. Daftar Pustaka}

Ahmad D. Marimba, Filsafat Pendidikan Islam, Al-Ma'arif:Bandung, 1980.cet. ke-4.

Daam Rahardjo, Intelektual Intlegensia dan Perilaku Politik Bangsa Risalah Cendekiawan Muslim. Mizan: Bandung. 1993.

Depdiknas, Manajemen Peningkatan Mutu Berbasis Sekolah, Buku 5: Pembelajaran dan Pengajaran Kontekstual. Dirjen Dikdasmen dan Direktorat SLTP. 2002.

Kompas, 'Pendidikan Sekolah Belum Menyenangkan" Jumat, 28 Februari 2003. 


\section{Ririn Suneti - Implementasi Pembelajaran Pendidikan ...}

Mulkan, et. al Abdullah, Amir. Problem Epistemologis-Metodologis Pendidikan Islam. Dalam Abdul Munir. Religius Iptek. Pustaka Pelajar: Yogyakarta. 1998.

Muhaimin.Pengembangan Kurikulum Pendidikan Agama Islam:di Sekolah, Madrasah, dan Perguruan Tinggi. GrafindoPersada:Jakarta.2005. Nana Syaodih Sukmadinata. Pengembangan Kurikulum: Teori dan Praktek. Rosdakarya: Bandung. 1999.

Muhaimin. Wacana Pengembangan Pendidikan Islam.Pustaka Pelajar: Surabaya. 2003.

Muhaimin. Pendidikan Agama Islam: Berwawasan Rekontruksi Sosial. UIN Press: Malang. 2004.

Noeng Muhadjir. Ilmu Pendidikan dan Perubaan Sosial: Teori Pendidikan Pelaku Sosial Kreatif. Rake Sarasin: Yogyakarta. 2000

Nasution, Kurikulum dan Pengajaran. Umi Aksara:jakarta. 1986.

Muhaimin. dkk. Paradigma Pendidikan Islam: Upaya Mengefektifkan Pendidikan Agama di Sekolah. Rosda Karya:Bandung. 2002.

Muhaimin, Arah Baru Pengembangan Pendidikan Islam: Pemberdayaan, Pengembangan Kurikulum hingga Redifinisi Islamisasi Pengetahuan. Nuansa Cendekian: Bandung. 2003.

Suparno, Paul. dkk. Reformasi Pendidikan: Sebuah Rekontruksi. Kanisius: Jakarta. 2002.

Zakiah Daradjat, Ilmu Pendidikan Islam.,Bumi Aksara:Jakarta,1991. 